\title{
Research on the Influence of Customer Experience upon Brand Loyalty of B2C Website
}

\author{
Yi Yang \\ Department of business \\ Guilin University of Electronic Technology \\ Guilin, Guangxi, China \\ 463760070@qq.com
}

\author{
Yao Cai \\ Department of business \\ Guilin University of Electronic Technology \\ Guilin, Guangxi, China \\ 741813966@qq.com
}

\begin{abstract}
In order to enhance customer's brand loyalty of B2C website and improve customer's repeat purchase rate in the website, this research based on the perspective of customer's online shopping experience. To conclude the influencing factors of consumer's brand loyalty to B2C website: website experience, logistics experience, product experience and after-sales experience. Finally, corresponding countermeasures and suggestions are proposed to improve customer's experience and brand loyalty to B2C website. Such as enhance the responsiveness of website's services, strengthen website's sensory experience; improve the order processing speed and the logistics service quality; rich the product information of website, provide competitive products; improve the quality of after-sales service, shape excellent service brand. This paper's innovation is that Consumers' shopping experience was analyzed from the online experience to offline experience. Therefore, the conclusions can be applied to $\mathrm{B} 2 \mathrm{C}$ website in some degree.
\end{abstract}

Keywords-customer experience; brand loyalty; B2C website;suggestions

\section{INTRODUCTION}

According to the monitoring data of China electronic commerce research center, in the first half of 2015 B2C online retail market share of the top four in China is in turn: Tmall ranks first, accounting for 57.7\%; Jingdong ranked second with $25.1 \%$ share, Suning purchase in third, accounting for $3.4 \%$ and fourth Vipshop 2.5\% share. By the end of June 2015, China's online shopping users to scale up to 417 million people, and the first half of 2014, 350 million, up 19.1\% year-on-year [1], This shows that with the popularity of the Internet and ecommerce, shopping through the website has become a way of life of Chinese consumers, even is a kind of entertainment to enjoy. Now, however, B2C shopping websites are increasingly showing a homogeneity phenomenon. At the same time, the competition between major shopping website also is increasingly fierce. How to promote customers' online shopping experience and customer satisfaction and maintain customer's brand loyalty to web sites becomes the common problem that the electric business enterprise faces.

Schmitt points out that the customer experience is an individualized feeling to certain stimuli. It is divided into five modules in Schmitt's paper: sense, feel, think, act, and relate

This work is supported by the national natural science fund project: research on consumers' brand perception differences about "domestic" and "import" brand and influence mechanism. The project number is 71262015 .
[2]. Products or services can create different types of experience for customers by adopting sensorial and infectious way. The value of a brand or product can be delivered continuously. Davenport thought, compared with the direct role in the physical environment of sensory experience, experience marketing in network replaces the direct experience in the real environment by web-interface [3]. For retailers, the challenge is to create a memorable and unparalleled experience through the electronic environment that makes the customer participation and motivation and obtains customer loyalty. Csikszentmihalyi mainly researched on consumers' psychological satisfaction in the process of online shopping [4]. He put forward the theory of flow experience and emphasized customers' immersion and input status. When individuals are in a state of Flow and completely attracted to do something, consumers feel very happy. Efthymios Constantinides insisted that experience factors can be divided into functional factors, psychological factors and content factors, included websites' ease of use, interactivity, trust, aesthetic and marketing mix [5].

Oliver, defined the brand loyalty as "consumers' deep promise to the brand", and consumers will repeat purchase the product or service in the future [6]. That is to say, even if customers are under the influence of the different situation or any marketing activity, they will still be repetitive to buy the same brand. Kalakota and Whinston pointed out that the brand loyalty on the Internet more fragile than others brand loyalty [7]. This is mainly because the information on the Internet is completely transparent. New technology and promotion methods will be imitated by competitors soon. This makes the differentiation advantage of the website difficult to maintain. Therefore, the B2C website brand loyalty researched in this paper refers to customers' brand loyalty to the B2C website. Namely, customers choose the website repeatedly to buy particular products or services.

The construction of customer's online shopping experience as the core of marketing task the e-business enterprise has aroused the concern of the society from all walks of life. More and more scholars committed to study the influence of customer's online shopping experience upon brand loyalty. A large number of studies have shown that customer's online shopping experience has a significant influence on consumers' brand loyalty. Now, the division of customer's online shopping experience is basically used Schmitt's model to 
divide into five types of experience. And few are divided from consumers' shopping experience at various stages in the process of web shopping. Therefore, according to the shopping experience at various stages in $\mathrm{B} 2 \mathrm{C}$ website, the influence factors that affect consumer's website brand loyalty are divided into website experience, logistics experience, product experience and after-sales experience.

\section{THE INFLUENCING FACTORS OF BRAND LOYALTY TO B2C WEBSITE}

\section{A. Website Experience}

The website experience refers to the emotion and value consumers perceived after browsing the shopping website. Scholars in the study, set the website experience as front variable, to study its effect to consumer's website brand loyalty, and verified. Therefore, this paper argues that the consumer's website experience is one of the factors affecting the brand loyalty to the website. Consumer's website experience includes consumer's perception of the quality of the website system, whether it has friendly interface design, is easy to operate, is convenient to order and payment, can let users accurately to retrieve to required commodity information. All of these will affect consumer's brand loyalty to shopping website [8]. Consumer's perception of website interactivity when shopping in website also affects consumer's website brand loyalty. Online sellers and consumers exchange product's information through B2C website. The interactive performance of website can effectively solve the situation of user's information asymmetry. The crux of the problem is that consumers' interactive experience in the website can successfully solve consumer's confusion and improve consumer's satisfaction. The third aspect is consumer's perception of entertaining when shopping in the website. For example, the website's content in addition to meeting the demand for product information, whether meeting the emotional needs of the consumers, whether shopping in the website can experience newfangled and interesting things.

\section{B. Logistics Experience}

Logistics experience refers to the efficiency of goods distribution and the reliability of logistics which consumers perceived after placing orders. Unlike traditional entity transactions, the accomplishment of e-commerce transactions has hysteresis; consumers still need to wait for goods delivery after successfully finishing order in the site. Therefore, logistics experience has the strong impact on consumer's consumption psychology and behavior. Logistics experience is also an important part of consumers' online shopping process. Processing an order and dispatching the goods timely and keeping the integrity of goods what are core content which online customer concerned. The B2C shopping website can provide high quality of distribution service; will directly affect consumers' buying experience. The Tmall, for instance, during the "a double tenth ", the total distribution of logistics can't keep up with the increase of orders. Which made a bad evaluation on shopping experience? In the future, consumers may avoid participating in such activities. Therefore, the reliability, professionalism and flexibility of the logistics are important to improve consumer's shopping experience.

\section{Product Experience}

Product experience refers to the function value and emotional satisfaction about the product. Product is the core content of B2C shopping website. On the one hand, in online trading environment, consumers will evaluate the value of the product itself; will compare information on the website of the product description with products received. They will measure the truthfulness, accuracy and cost performance of the goods. The primary value what consumers measured is that the function value of product. Namely, the price, quality and style of the product whether achieve the expected value and meet their needs. On the other hand, consumers have emotion demand for the product they buy. He hopes to receive or use of products with happy mood. He wants to gain recognition from his friends or relatives. The emotional experience of product is as important as the function value of the product itself. Sometimes, consumers are willing to pay even a higher premium for hedonic demand. This will improve consumer's product experience. Thus consumer's brand loyalty to the shopping website will also be improved. Once consumers have a bad experience in shopping website, they will transfer to other B2C website to buy the product.

\section{After-sales Experience}

After-sales experience, it is to point to various services' quality provided by online sellers or websites platform after goods deal. As electronic commerce is remote transaction in virtual environments, when the quality of goods goes wrong, whether it is convenient to return or exchange goods in B2C shopping website, or whether the procedure is simple, or to provide a good after-sale security policies, whether the complaints mechanism of website is perfect. All of these are undoubtedly the questions consumers worry about. After-sale service has become the key factor for B2C enterprise to maintain or increase market share. The quality of after-sales service can affect consumers' shopping satisfaction and website brand loyalty. When consumers are browsing product information in the website, quality guarantee system, aftersales service and other relevant regulations can make customers get rid of the doubt and promote their purchase intention. Providing return service with low price can promote consumers' shopping tendencies. Consumers' shopping in website with good after-sales experience can increase consumers' repeat purchase rate and improve brand loyalty. In today's fierce market competition, with the improvement of consumers' rights consciousness and the change of consumption idea, consumers no longer only focus on the product itself. With similar quality and performance between congeneric products, consumers prefer to choose these B2C websites with high quality of after-sales service.

\section{COUNTERMEASURES AND SUGGESTIONS}

Above analysis for B2C website brand loyalty suggests that website experience, logistics experience, product experience and after-sales experience will affect customer's satisfaction and the website brand loyalty, thus improve consumers' repeat purchase rate. Therefore, in order to improve B2C website brand loyalty, some efforts can be made from the following aspects. 


\section{A. Enhance the Responsiveness of Website's Services, Strengthen Website's Sensory Experience}

Responsiveness refers to the fluency to open the interface of goods link and the immediacy to respond to consumer's consultation when consumers are in online interactions with website. In online environments, consumer's conversion cost is low. Therefore, online sellers or B2C websites platform should give a response in a timely manner for any interaction from customers. It is important to retain customers, have the initiative in hands and build customer loyalty [9]. In addition, B2C website should also establish a friendly interface and give consumers good experience from the visual and auditory sensory, which makes consumer feel happy when shopping in this B2C website. From consumers click on the product to place an order successful, B2C website should give consumers smooth and intimate experience. At the same time, it will provide entertaining feel for consumers during shopping in B2C website. This needs to improve the quality of web design, web services and web system [10].

\section{B. Improve the Order Processing Speed and the Logistics Service Quality}

Improving consumer's whole shopping experience, logistics experience is one of the most important content. First of all, after consumers placing the order, online sellers should speed up the processing speed of order and distribute goods in a timely manner. Online sellers should choose logistics company with good word of mouth and fast efficiency to dispatch goods. Second, some websites have post-purchase evaluation of logistics services. But many websites or online sellers are lack of evaluation after the inspection stage. Therefore, websites or online sellers can assess logistics company service level according to consumer's grade. In order to improve the consumer's evaluation of logistics, the logistics company with lower scores should change in time. Only by doing that, consumers' logistics experience can be improved. Secondly, for large sales promotion activity of B2C website, the logistics company should prepare for good logistics in advance, the goods should be transported to the warehouse which is close to consumers. Finally, with the development of B2C shopping website enterprise, the company with solid strength and rich resource can consider the self-built logistics. It can alleviate the pressure of logistics distribution and control the quality of logistics distribution. Involving in first-tier cities can use selfbuilt logistics distribution, and the second - and third-tier cities and remote areas of logistics can be outsourced to the third party logistics. It can save costs, improve consumer logistics experience and improve consumer's brand loyalty to the website.

\section{Rich the Product Information of Website, Provide Competitive Products}

On the one hand, B2C shopping website should provide comprehensive product information as much as possible. Due to the detailed product information is important for consumers to understand the product, and will directly affect consumers' perceived risks, which cause the propensity to buy. Therefore, the introduction of product's information should be accurate and complete. It is also important to provide all-round display of product and offer a large number of similar goods available. The reason is that the conversion cost is very low in website shopping. When shopping online, consumers will compare the prices, function and evaluation of similar products in several websites. For example, providing functionality and price comparisons between different products, experts or the user's evaluation to goods are convenient for consumer's decision making. On the other hand, many consumers are shopping online not only for entertainment needs, but also for a lower discount. Consumers are sensitive to the price of website product. And consumers will compare product's price between different websites, and select goods with high cost performance to buy. Therefore, providing goods with good quality and competitive price are the core content of B2C website.

\section{Improve the Quality of After-sales Service, Shape Excellent Service Brand}

Now the trend of the electricity supplier homogenization is becoming more and more serious, the price war between electric business website also plays more and more fiercely. In addition comparing site experience and product experience, consumers are especially focused on the after-sales service quality of B2C website. Now buying products online, there is a high rate of return of goods. So, reducing consumers' costs to return and exchange goods and improving service responsiveness are notable content. On one hand, perfecting after-sales service guarantee measures, such as a money-back guarantee, goods placement, etc., all of these are important to improve consumer's shopping experience. On the other hand, consumer protection policy should be formulated. The price and brand of the product can directly affect consumers' perceived risk. So website can provide diversified methods to pay, after-sales service and guarantee measures to enhance consumer's credibility about goods and website. Choosing the products with high brand awareness to sell will reduce consumer's perceived risk caused by the price and brand. And promise after-sales service quality, which can improve consumer's shopping experience. In the long run, it could be also helpful to shape the positive image of B2C website brand.

\section{CONCLUSION}

In conclusion, when shopping in the B2C website, consumer's web experience, logistics experience, products experience and after-sales service experience will affect consumers' satisfaction, which influences to brand loyalty. In order to improve website experience, the B2C business should improve the responsiveness of web service and strengthen the website's sensory experience. At the same time, in order to increase consumers' evaluation of logistics experience, the speed of processing order and the quality of logistics service must be improved. The B2C website should enrich product information and provide competitive products for consumers, to increase consumers' repeat purchase rate in the website. After-sales service as one of the most important links, B2C business must improve the quality of after-sales service, and create excellent service brand image.

In this paper, the dimension of customer experience is divided according to consumers' shopping process in the online. This provides a new perspective to study customer 
experience on brand loyalty. At the same time, the conclusions of this article have a certain theoretical guidance to the $\mathrm{B} 2 \mathrm{C}$ business. But this paper also has certain limitation. This article mainly uses the qualitative analysis method and lacks data support. Hope in the later study, we can add data and use quantitative analysis to prove that customer experience affects consumers brand loyalty to B2C website.

\section{REFERENCES}

[1] The China electronic commerce research center. In 2015 China's online retail market data monitoring report [R]. Hangzhou. China's e-commerce research center, 2015.

[2] Schmitt B H. "Experiential Marketing: How to Get Customers to Sense, Feel, Think, Act, and Relate to Your Company and Brands,”M. New York: The Free Press, 1999.

[3] Davenport T, Beck J. The Attention Economy: Understanding the New Currency of Business[M].Boston: Harvard Business School Press, MA, 2002.
[4] Csikszentmihalyi I, Csikszentmihalyi M. Optimal Experience: Psychological Studies of Flow in Consciousness[M]. NewYork: Cambridge University Press, 1988.

[5] Efthymios Constantinides, Peter Geurts. The Impacts of Web Experience on Virtual Buying Behavior: An Empirical Study[J]. Journal of Customer Behavior, 2005(4):307- 336.

[6] Oliver R L. Whence Consumer Loyalty[J]. Journal of Marketing, 1999, 63(Special Issue):33- 44.

[7] Kalakota Ravi, Whinston Andrew. Frontiers of Electronic Commerce[M]. Addison Wesley, 1996.

[8] Srinivasan S S, Anderson R, Ponnavolu K. "Customer loyalty in ecommerce: an exploration of its antecedents and consequences," J. Journal of retailing, 2002, pp. 41-50.

[9] Stone M, Woodcock N, Machtynger L. "Customer relationship marketing: Get to know your customers and win their loyalty,”M. Kogan Page Publishers,2000.

[10] Krawczyk A C. Linking the customer purchase process to website development and e-commerce performance[M]. PPI Publishers, 2008. 